\title{
Kontribusi Kecerdasan Interpersonal dan Aktualisasi Diri dalam Kelompok Terhadap Kompetensi Pengetahuan IPS
}

\author{
*I Gst. A. Ratih Pratiwi¹ I.B. Surya Manuaba², I W. Sujana ${ }^{3}$ \\ ${ }^{123}$ Prodi PGSD, Jurusan Pendidikan Dasar, FIP Universitas Pendidikan Ganesha, Singaraja, Indonesia
}

\section{A R T I C L E I N F O}

Article history:

1 Maret 2020 Received in

revised form

30 Maret 2020

Accepted 11 April 2020

Available online 15

Mei 2020

Kata Kunci:

aktualisasi diri, kecerdasan interpersonal, kompetensi

Keywords: self

actualization, interpersonal intelligence, competencies

\begin{abstract}
A B S T R A K
Penelitian ini bertujuan untuk mengetahui kontribusi yang signifikan kecerdasan interpersonal terhadap kompetensi pengetahuan IPS, kontribusi yang signifikan aktualisasi diri dalam kelompok terhadap kompetensi pengetahuan IPS, kontribusi yang signifikan secara bersama-sama kecerdasan interpersonal dan aktualisasi diri dalam kelompok terhadap kompetensi pengetahuan IPS siswa kelas V. Jenis penelitian ini adalah ex-post facto. Populasi dalam penelitian ini adalah seluruh siswa kelas V SD yang berjumlah 300 siswa. Penentuan sampel menggunakan teknik proporsional random sampling sehingga hasilnya sebanyak 166 siswa. Pengumpulan data menggunakan metode kuesioner untuk mengukur kecerdasan interpersonal dan aktualisasi diri dalam kelompok, sedangkan data mengenai kompetensi pengetahuan IPS diperoleh melalui pencatatan dokumen. Teknik analisis data yang digunakan yaitu analisis regresi linier ganda. Hasil Penelitian
\end{abstract} menunjukkan bahwa terdapat pengaruh yang signifikan kecerdasan interpersonal terhadap kompetensi pengetahuan IPS dengan kontribusi sebesar 3,75 \%, terdapat pengaruh yang signifikan aktualisasi diri dalam kelompok terhadap kompetensi pengetahuan IPS dengan kontribusi sebesar $3,76 \%$, serta terdapat pengaruh yang signifikan secara bersama-sama antara kecerdasan interpersonal dan aktualisasi diri dalam kelompok terhadap kompetensi pengetahuan IPS dengan kontribusi sebesar 7,51\%. Dapat disimpulkan bahwa kecerdasan interpersonal dan aktualisasi diri dalam kelompok berkontribusi terhadap kompetensi pengetahuan IPS siswa kelas V SD Gugus Budi Utomo Kecamatan Denpasar Timur Tahun Pelajaran 2019/2020.

\section{A B S T R A C T}

This study aimed to determine the significant contribution of interpersonal intelligence to social science knowledge competencies, the significant contribution of self-actualization in groups to social science knowledge competencies, the significant contribution of interpersonal intelligence and selfactualization in groups on the competence of social science knowledge of 5th grade. This type of research was ex-post facto. The population in this study were all 5th grade students of SD Gugus Budi Utomo in East Denpasar District, totaling 300 students. Sampling technique used was proportional random sampling and the result was 166 students. Data collection was using questionnaire method to measure interpersonal intelligence and self-actualization in groups, while data on social science knowledge competencies were obtained through document recording. The assumption test used was the normality test, linearity test, multicollinearity test, and heterokedasticity test. Data analysis techniques used were multiple regression analysis to test hypothesis. The results show that interpersonal intelligence has a positive and significant effect on the social science knowledge competence with a contribution of 3,75\%, self-actualization in the group has a positive and significant effect on social science knowledge with a contribution of 3,76\%, interpersonal intelligence and selfactualization in groups simultaneously have significant effect on the competence of social science knowledge with a contribution of $7.51 \%$. It is concluded that interpersonal intelligence and selfactualization within the group contribute to the knowledge competence of social studies students of the 5th grade of SD Budi Utomo in East Denpasar District in 2019/2020 Academic Year.

Copyright (C) Universitas Pendidikan Ganesha. All rights reserved

Corresponding author

E-mail addresses: agung.ratih.pratiwi@undiksha.ac.id(Ratih) ${ }^{1}$, idabagussurya.manuaba@undiksha.ac.id(Manuaba)2

iwayan.sujan@undiksha.ac.id(Sujana) ${ }^{3}$ 


\section{Pendahuluan}

Kurikulum merupakan bagian dari sistem pendidikan yang tidak bisa dipisahkan dengan komponen sistem lainnya, tanpa kurikulum suatu sistem pendidikan tidak dapat dikatakan sebagai sistem pendidikan yang sempurna. Kurikulum yang diberlakukan di Indonesia saat ini adalah Kurikulum 2013 dimana kurikulum ini lebih menekankan pada kompetensi dengan pemikiran berbasis sikap, keterampilan dan pengetahuan. Kurikulum 2013 menghasilkan "insan yang produktif, kreatif, inovatif, dan afektif serta lebih menekankan pada kompetensi berbasis sikap, keterampilan, dan pengetahuan" (Daryanto, 2013:5). Harapan dari adanya kurikulum 2013 adalah untuk menyiapkan generasi yang handal, inovatif dan berkarakter serta siap mengarungi tantangan zaman dimasa yang akan datang (Muzamiroh, 2013:119). Menurut (Luh et al., 2016) pada kurikulum 2013 di setiap jenjangnya menerapkan pembelajaran berbasis tematik integratif. Salah satu inovasi pembelajaran yang dinilai sejalan dengan kurikulum 2013 yaitu pembelajaran kooperatif. Implementasi dari pembelajaran kooperatif ini yaitu siswa didalam satu kelas dibentuk berdasarkan kelompok yang heterogen. Didalam kelompok yang heterogen siswa memiliki tingkat kecerdasan dan sifat yang berbeda-beda yang menjadikan siswa harus mampu menjalin hubungan yang baik dengan anggota kelompok. Salah satu implementasi pembelajaran koperatif adalah siswa bekerjasama secara kolaboratif yang dilandaskan dengan karakter gotong royong membuat para guru dalam melaksanakan kegiatan belajar mengajar mengelompokkan siswanya yang mendorong membangun kompetensi sosial siswa.

Menurut Kurniasih (2014: 19), kompetensi adalah kemampuan, kecakapan, keterampilan, dan pengetahuan seseorang di bidang tertentu. Menurut Suriasumantri (Sakti, 2011) juga menyatakan bahwa pengetahuan adalah semua hal yang diktahui manusia mengenai suatu objek untuk mengembangkan mental yag dimiliki baik langsng maupu tidak langsung. Jadi, kompetensi pengetahuan merupakan penilaian yang dilakukan guru pada ranah kognitif untuk mengukur tingkat pencapaian atau penguasaan peserta didik dalam aspek pengetahuan. Salah satu kompetensi yang berpengaruh di SD adalah Kompetensi Pengetahuan IPS karena fokus utama dari pembelajaran IPS adalah membentuk individuindividu dalam memahami kehidupan sosialnya, aktivitas, dan interaksinya yang ditunjukan untuk menghasilkan anggota masyarakat yang bebas, yang mempunyai rasa tanggung jawab untuk melestarikan, melanjutkan, dan memperluas nilai-nilai dan ide masyarakat bagi generasi masa depan. Menurut Susanto (Giri et al., 2018) Ilmu Pengetahuan Sosial (IPS) merupakan "ilmu yang mengarahkan peserta didik untuk melakukan interaksi dengan lingkungan sekitar". Ilmu Pengetahuan Sosial (IPS) merupakan ilmu yang mengarahkan peserta didik untuk melakukan interaksi dengan lingkungan sekitar baik itu dengan manusia lainnya, benda kebutuhan hidup, lembaga, ataupun dengan lingkungan itu sendiri (Amalia, 2017)). Pembelajaran IPS di SD bertujuan untuk mengenalkan konsep-konsep yang berkaitan dengan lingkungan dan kehidupan bermasyarakat, memiliki kesadaran terhadap nilai-nilai sosial dan kemanusiaan, memiliki kemampuan bekerjasama, berkomunikasi serta berkompetisi dalam masyarakat yang majemuk, dan memiliki kemampuan dasar untuk berpikir logis, kritis, rasa ingin tahu yang tinggi, inkuiri, mampu memecahkan masalah dan memiliki keterampilan dalam kehidupan sosial (Ayu Wardani et al., 2019)). dalam memperoleh kecerdasan interpersonal. Kecerdasan interpersonal ini memiliki keterkaitan antara tujuan pembelajaran IPS dengan konsep-konsep maupun dimensi-dimensi yang terdapat dalam kecerdasan interpersonal.

Kecerdasan interpersonal merupakan salah satu bagian dari Multiple Intelligences. Kecerdasan ini berkaitan dengan kehidupan sosial seperti: berteman, bergaul atau bersosialisasi dengan orang lain, dan bekerja atau bermain secara berkelompok (Amitha, 2016). Menurut Armstrong (2002:7) menyatakan "kecerdasan interpersonal adalah kemampuan untuk memahami dan membuat perbedaan-perbedaan pada suasana hati, maksud, motivasi, dan perasaan terhadap orang lain”. (Safaria, 2005) menyatakan "kecerdasan interpersonal menjadi penting karena pada dasarnya manusia tidak dapat hidup sendiri, karena pada kegiatan apapun manusia dituntut untuk berhubungan sosial dengan orang lain”. Kecerdasan interpersonal seseorang dapat diamati melalui perilakunya. (Monawati, 2017) juga menyatakan bahwa kecerdasan interpersonal adalah kemampuan lebih untuk menjalin suatu relasi dengan orang lain, membaca kondisi serta karakter seseorang serta bagaimana beradaptasi dan menempatkan diri dalam berbagai kondisi. Oleh karena itu, kecerdasan ini dapat dikembangkan oleh setiap anak, namun dalam pengembangannya tetap membutuhkan bimbingan dari orang tua dan pendidik. Dalam kecerdasan interpersonal terdapat beberapa dimensi atau bagian bagian yang menyusun kecerdasan interpersonal. Dimensi-dimensi ini menelaah tentang indikator-indikator yang wajib dimiliki oleh seseorang yang memiliki kecerdasaan interpersonal. Terdapat tiga dimensi kecerdasan interpersonal menurut Safaria (2005:24), yaitu "sensivitas sosial (social sensitivy), pemahaman sosial (social insight), dan komunikasi sosial (social communication)". Dengan kecerdasan ini siswa lebih mudah mengikuti pembelajaran di dalam kelas karena siswa yang memiliki kecerdasan interpersonal memiliki kemampuan dalam 
bekerjasama dengan teman-temanya dikelas, menyukai kegiatan berkelompok, dan memiliki kemampuan dalam berkomunikasi dengan orang lain sehingga siswa dapat mengetahui dan mengukur potensi yang terdapat di dalam diri siswa tersebut secara optimal (Nurjanah, 2016)

Setiap siswa memiliki potensi diri yang perlu dikembangkan agar bermanfaat dalam kehidupannya (L.Bernadeta, 2017). Potensi pada setiap anak merupakan dasar untuk menjadi generasi yang unggul dalam suatu negara yang dipengaruhi oleh pemenuhan kebutuhan-kebutuhan dasar. Maslow (dalam Prawira, 2014) menyebutkan bahwa kebutuhan manusia meliputi kebutuhan biologis (sandang, pangan, papan, dan kesehatan) serta kebutuhan psikologis (rasa aman, self esteem, dan kasih sayang). Kebutuhankebutuhan tersebut harus terpenuhi sehingga mencapai tingkat kebutuhan dasar manusia yang paling tinggi yaitu kebutuhan aktualisasi diri. Kebutuhan aktualisasi diri menjadi kebutuhan tertinggi dalam hierarki kebutuhan manusia, yakni kebutuhan dalam pencapaian potensi diri sepenuhnya (Ria Sabekti, Ah Yusuf, 2019). Menurut Maslow (1984) dalam bukunya yang berjudul Motivation and Personality menggunakan istilah aktualisasi diri (self actualization) sebagai kebutuhan dan pencapaian tertinggi seorang manusia. Untuk mengambangkan potensi siswa tersebut diperlukan pemahaman terhadap potensi yang dimiliki. Potensi diri yang telah nampak secara nyata dalam bentuk aktivitas dinamakan dengan aktualisasi diri. Menurut Maslow (dalam Sudarsana, 2017) aktualisasi diri adalah penggunaan atau pemanfaatan bakat, potensi, pada diri individu secara penuh. Orang yang mampu mengaktualisasikan diri mempunyai kecenderungan untuk menjalin hubungan yang baik dengan orang lain. Ia dapat menjalin hubungan yang akrab dengan penuh rasa cinta dan kasih sayang.

Aktualisasi diri memudahkan dan meningkatkan pematangan dan pertumbuhan, serta bisa mengalami perubahan seiring berkembangnya hidupnya seseorang (Daniati, Hermi Yanzi, 2015). Apabila siswa mampu menata dan mengembangkan potensinya maka tentu mempermudah dalam mengikuti pembelajaran di sekolah. Pada saat proses belajar ini siswa akan menemukan kecocokan yang sesuai dengan potensi kepribadiannya. Seseorang yang telah mencapai aktualisasi diri dengan optimal memiliki kepribadian yang lebih baik daripada manusia pada umumnya. Salah satu karakteristik yang menunjukan seseorang mencapai aktualisasi diri adalah memiliki hubungan interpersonal yang baik. Dengan demikian maka orang yang mampu mengaktualisasikan diri mempunyai kecenderungan untuk menjalin hubungan yang baik dengan orang lain (hubungan interpersonal) yang dipengaruhi oleh kecerdasan interpersonalnya.

Berdasarkan hasil pengamatan dan wawancara yang didapat dari wali kelas V SD di Gugus Budi Utomo, pada saat proses belajar IPS yang menggunakan bentuk belajar berkelompok, siswa dituntut untuk melakukan kerjasama dengan teman sekelompoknya, saat dilaksanakan pembelajaran kelompok masih terdapat siswa yang kesulitan untuk berinteraksi dan bekerjasama dengan teman di kelompoknnya, sehingga jika siswa memiliki kecerdasan interpersonal yang rendah maka siswa tidak mampu memahami serta membangun relasi dengan teman di kelompoknya. Selain itu, pada saat proses pembelajaran berkelompok ditemui pula siswa yang belum bertanggung jawab dalam mengerjakan tugas yang diberikan oleh guru di dalam kelompoknya, egois dengan temannya, dan saling mengejek ketika temannya tidak bisa mengerjakan masalah yang diberikan oleh gurunya, kurangnya aktualisasi diri dari siswa di kelompoknya ini mempengaruhi kompetensi pengetahuan IPS. Siswa yang memiliki masalah dalam pencapaian kompetensi pengetahuan IPS, memiliki sifat agresif terhadap teman-teman di kelompoknya, siswa ini juga cenderung takut berpendapat dan tidak mampu mengambil keputusan sendiri ketika guru mengajukan pertanyaan. Rata-rata siswa masih belum optimal dalam pencapaian kompetensi pengetahuan IPS. Belum optimalnya kompetensi pengetahuan IPS tersebut dilihat dari banyak siswa yang mempunyai nilai di bawah ketuntasan kriteria minimal (KKM). Dimana KKM yang diharapkan untuk kompetensi pengetahuan IPS siswa kelas V SD Gugus Budi Utomo Denpasar Timur adalah 75,00. Jumlah seluruh siswa SD kelas V di SD Gugus Budi Utomo yaitu 300 siswa, sebanyak 184 siswa (61\%) belum mampu mencapai nilai kriteria ketuntasan minimal dalam kompetensi pengetahuan IPS. Dan 116 siswa (39\%) sudah mampu mencapi nilai kriteria ketuntasan minimal dalam kompetensi pengetahuan IPS. Pada data hasil ulangan akhir semester 1 pada muatan materi IPS, nilai rata-rata siswa kelas V SD di Gugus Budi Utomo Tahun Pelajaran 2019/2020 masih berada dibawah nilai kriteria ketuntasan minimal. Bertitik tolak dari masalah tersebut dan untuk mengetahui sejauh mana hubungan kecerdasan interpersonal dan aktualisasi diri dalam kelompok terhadap kompetensi pengetahuan IPS maka dilaksanakan penelitian yang berjudul Kontribusi Kecerdasan Interpersonal dan Aktualisasi Diri dalam Kelompok terhadap Kompetensi Pengetahuan IPS Siswa Kelas V SD Gugus Budi Utomo Kecamatan Denpasar Timur Tahun Pelajaran 2019/2020.

Penelitian ini bertujuan untuk mengetahui kontribusi yang signifikan antara kecerdasan interpersonal terhadap kompetensi pengetahuan IPS siswa kelas V SD Gugus Budi Utomo Kecamatan

I Gst. A. Ratih Pratiwi ${ }^{1}$ I.B. Surya Manuaba² I W. Sujana ${ }^{3 /}$ Kontribusi Kecerdasan Interpersonal dan Aktualisasi Diri Dalam Kelompok Terhadap Kompetensi Pengetahuan IPS Siswa Kelas V 
Denpasar Timur, untuk mengetahui kontribusi yang signifikan antara aktualisasi diri dalam kelompok terhadap kompetensi pengetahuan IPS siswa kelas V SD Gugus Budi Utomo Kecamatan Denpasar Timur. Serta untuk mengetahui kontribusi yang signifikan antara kecerdasan interpersonal dan aktualisasi diri dalam kelompok terhadap kompetensi pengetahuan IPS siswa kelas V SD Gugus Budi Utomo Kecamatan Denpasar Timur Tahun Pelajaran 2019/2020. Penelitian relevan yang mendukung pemikiran tentang kecerdasan interpersonal dilaksanakan oleh Saputra (2018) yang membuktikan adanya hubungan yang signifikan antara kecerdasan interpersonal dengan hasil belajar IPS siswa serta penelitian yang dilaksanakan oleh Arum (2017) untuk membuktikan adanya hubungan yang signifikan antara kecerdasan interpersonal dengan hasil belajar IPS, selain itu penelitian yang mendukung pemikiran tentang aktualisasi diri dalam kelompok yaitu penelitian yang dilaksanakan oleh Sinambela (2016) dalam penelitiannya mengenai aktualisasi diri yang menyatakan terdapat pengaruh positif dan signifikan variabel aktualisasi diri terhadap prestasi belajar ekonomi siswa kelas XI tahun pelajaran 2015/2016.

\section{Metode}

Penelitian ini dilaksanakan pada siswa kelas V SD Gugus Budi Utomo Kecamatan Denpasar Timur Tahun Pelajaran 2019/2020. Penelitian ini pada dasarnya bertujuan untuk mengetahui kontribusi antara kecerdasan interpersonal dan aktualisasi diri dalam kelompok terhadap kompetensi pengetahuan IPS siswa kelas V SD Gugus Budi Utomo Kecamatan Denpasar Timur Tahun Pelajaran 2019/2020, dengan tidak memanipulasi variabel bebas atau menggali fakta yang sudah terjadi sebelumnya sehingga penelitian ini tergolong penelitian ex post facto dengan jenis studi korelasi.

Penelitian ex post facto adalah penyelidikan empiris sistematis, peneliti tidak mengendalikan variabel bebas secara langsung karena perwujudan variabel bebas tersebut telah terjadi, atau karena variabel tersebut pada dasarnya memang tidak dimanipulasi. Simpulan tentang adanya hubungan antara variabel tersebut dibuat berdasarkan perbedaan yang mengiringi variabel bebas dan variabel terikat tanpa intervensi langsung. Dantes (2012 :61) mengemukakan bahwa ex post facto mulai dengan kelompok-kelompok yang berbeda dan penelitian berusaha menentukan penyebab perbedaan-perbedaan. Variabel bebas dalam penelitian ini adalah kecerdasan interpersonal dan aktualisasi diri dalam kelompok, sedangkan variabel terikat dalam penelitian ini adalah kompetensi pengetahuan IPS siswa kelas V SD Gugus Budi Utomo Kecamatan Denpasar Timur Tahun Pelajaran 2019/2020. Populasi dalam penelitian ini adalah seluruh siswa kelas V SD Gugus Budi Utomo Kecamatan Denpasar Timur Tahun Pelajaran 2019/2020. yang terdiri dari 7 sekolah sebanyak 300 siswa. Teknik penentuan anggota sampel dalam penelitian ini menggunakan teknik proporsional random sampling. Menurut Agung (2014:55) Proporsional random sampling, yaitu sampling random yang memerhatikan perimbangan tiap kelompok sub-populasi sekolah. Penentuan ukuran sampel menggunakan tabel dari Isaac and Michael. Tabel tersebut terdapat besarnya sampel yang diambil dari populasi dengan tingkat kesalahan 1\%, 5\% dan 10\% Sugiyono (2017:71). Jadi, jumlah sampel minimal dengan jumlah populasi 300 orang untuk derajat kebebasan 1 dan kesalahan 5\% adalah 166 orang. Dengan rinciannya disajikan pada Tabel 01.

Tabel 01. Jumlah Populasi dan sampel siswa kelas V SD Gugus Budi Utomo Kecamatan Denpasar Timur

\begin{tabular}{ccccc}
\hline No. & Sekolah & Kelas & Populasi & Sampel \\
\hline 1. & \multirow{2}{*}{ SD Negeri 1 Kesiman } & VA & 33 & 18 \\
\cline { 2 - 5 } & SD Negeri 2 Kesiman & VB & 34 & 19 \\
\hline 2. & SD Negeri 5 Kesiman & V & 32 & 18 \\
\hline 3. & \multirow{2}{*}{ SD Negeri 6 Kesiman } & VA & 33 & 19 \\
\hline 4. & SD Negeri 8 Kesiman & VB & 33 & 18 \\
\hline 6. & SD Negeri 11 Kesiman & V & 36 & 18 \\
\hline 7. & SD Negeri 14 Kesiman & V & 34 & 19 \\
\hline 8. & Jumlah & $\mathbf{1 0}$ & $\mathbf{3 0 0}$ & $\mathbf{1 6 6}$ \\
\hline
\end{tabular}

Metode pengumpulan data pada penelitian ini menggunakan metode non tes. Sudijono (2015:76) menyatakan bahwa "teknik non tes biasanya dilakukan dengan cara wawancara, pengamatan secara sistematis, menyebarkan kuesioner, ataupun mengamati dokumen - dokumen". Yang tergolong teknik non tes adalah angket/kuesioner, wawancara, pengamatan dan riwayat hidup(Arikunto, 2015). Instrumen yang digunakan pada penelitian ini yaitu instrumen kuesioner untuk mengetahui atau mengukur 
kecerdasan interpersonal dan aktualisasi diri dalam kelompok, sedangkan instrumen yang digunakan untuk mengetahui Kompetensi Pengetahuan IPS adalah pencatatan dokumen berupa nilai ulangan semester 1 tahun ajaran 2019/2020. Kuesioner yang digunakan dalam penelitian ini adalah kuesioner tertutup dan langsung, artinya pernyataan-pernyataan yang diberikan kepada responden dalam menjawab tinggal memilih dengan memberi tanda pada alternatif jawaban yang tersedia. Pada penelitian ini, kuesioner disusun menggunakan skala Likert yang berjenjang dari satu sampai empat.. Dengan skala Likert maka variabel yang diukur dijabarkan menjadi indikator-indikator, kemudian indikator tersebut menjadi titik tolak untuk menyusun item-item instrumen yang dapat berupa pernyataan atau pertanyaan. Sebelum dilakukan uji coba instrumen, pada kuesioner kecerdasan interpersonal yang terdiri dari 7 indikator dan 33 butir pernyataan, sedangkan pada kuesioner aktualisasi diri dalam kelompok terdiri dari 10 indikator dan 30 butir pernyataan.

Instrumen yang digunakan dalam penelitian ini harus memiliki validitas dan reliabilitas. Uji validitas yang digunakan yaitu validitas konstruk dan validitas butir. Validitas konstruk merupakan suatu kondisi dimana sebuah instrumen yang disusun berdasarkan konstruk yang diukur dengan berlandaskan teori tertentu yang selanjutnya dikonsultasikan kepada ahli materi sedangkan validitas butir adalah sebuah item/butir yang dikatakan valid apabila mempunyai dukungan yang besar terhadap skor total. Pengukuran validitas tiap butir kuesioner dalam penelitian ini menggunakan rumus korelasi Product Moment. Menurut Sudjana dalam (Artha Saputra, I Wyn. Sujana, 2018) Reliabilitas adalah ketetapan atau keajegan instrument tersebut dalam menilai. Untuk menghitung reliabilitas instrumen menggunakan koefisien alpha cronbach, namun pada penelitian ini uji validitas dan reliabilitas dilakukan dengan analisis pada aplikasi Microsoft Excel 2010. Instrumen angket kecerdasan interpersonal dan aktualisasi diri dalam kelompok yang telah dirancang dan lulus uji validitas konstruk, selanjutnya diuji cobakan. Uji coba di lapangan pada penelitian ini dilakukan di SD Negeri 5 Kesiman yang berjumlah 34 siswa. Setelah uji coba instrumen diperoleh 30 pernyataan yang valid dengan reliabilitas sebesar 0,840 yang berarti reliabilitas instrumen sangat tinggi untuk kuesioner kecerdasan interpersonal dan 29 pernyataan yang valid dengan reliabilitas sebesar 0,846 yang berarti reliabilitas instrumen tinggi untuk kuesioner aktualisasi diri dalam kelompok.

Selanjutnya dilakukan analisis data. Dalam penelitian ini analisis data yang digunakan adalah analisis statistik inferensial. Uji hipotesis menggunakan teknik analisis regresi ganda. Teknik analisis regresi ganda merupakan bagian dari analisis multivariat dengan tujuan menduga besarnya koefisien regresi yang akan menunjukkan besarnya pengaruh beberapa variabel bebas terhadap variabel terikat. Sebelumnya dilakukan uji asumsi yaitu uji normalitas, uji linieritas, uji multikolinearitas, dan uji heteroskesdastisitas. Adapun hipotesis yang diuji dalam penelitian ini yaitu hipotesis nol $\left(\mathrm{H}_{0}\right)$, yaitu : (1) tidak terdapat pengaruh yang signifikan antara kecerdasan interpersonal terhadap kompetensi pengetahuan IPS siswa kelas V SD Gugus Budi Utomo Kecamatan Denpasar Timur Tahun Pelajaran 2019/2020, (2) tidak terdapat pengaruh yang signifikan antara aktualisasi diri dalam kelompok terhadap kompetensi pengetahuan IPS siswa kelas V SD Gugus Budi Utomo Kecamatan Denpasar Timur Tahun Pelajaran 2019/2020, dan (3) tidak terdapat pengaruh yang signifikan antara kecerdasan interpersonal dan aktualisasi diri dalam kelompok terhadap kompetensi pengetahuan IPS siswa kelas V SD Gugus Budi Utomo Kecamatan Denpasar Timur Tahun Pelajaran 2019/2020.

\section{Hasil dan pembahasan}

Data yang diperoleh dari hasil penelitian ini adalah data nilai kompetensi pengetahuan IPS siswa, hasil kuesioner kecerdasan interperseonal dan hasil kuesioner aktualisasi diri dalam kelompok siswa kelas V SD Gugus Budi Utomo Kecamatan Denpasar Timur yang dijadikan sampel dalam penelitian ini. Rangkuman analisis deskripsi data hasil penelitian yang diperoleh disajikan pada Tabel 02.

Tabel 02. Rangkuman Hasil Analisis Deskritif Data Penelitian

\begin{tabular}{llll}
\hline Statistik & $\begin{array}{l}\text { Kompetensi } \\
\text { Pengetahuan IPS }\end{array}$ & $\begin{array}{l}\text { Kecerdasan } \\
\text { Interpersonal }\end{array}$ & $\begin{array}{l}\text { Aktualisasi Diri } \\
\text { Dalam Kelompok }\end{array}$ \\
\hline $\mathrm{N}$ & 166 & 166 & 166 \\
Rata - rata (Mean) & 78,07 & 80,50 & 81,72 \\
Standar Deviasi & 7,08 & 10,77 & 8,38 \\
Varian & 50,22 & 116,15 & 70,38 \\
Modus & 72,71 & 74,61 & 76,8
\end{tabular}

I Gst. A. Ratih Pratiwi ${ }^{1}$ I.B. Surya Manuaba² I W. Sujana ${ }^{3 /}$ Kontribusi Kecerdasan Interpersonal dan Aktualisasi Diri Dalam Kelompok Terhadap Kompetensi Pengetahuan IPS Siswa Kelas V 


\begin{tabular}{llll} 
Median & 63,19 & 59,53 & 65 \\
Skor Maksimum & 97 & 106 & 101 \\
Skor Minimum & 65 & 52 & 62 \\
\hline
\end{tabular}

Sebelum dilakukan pengujian hipotesis dengan analisis regresi linier ganda, data yang diperoleh terlebih dahulu dilakukan uji asumsi yang mencakup 4 uji yakni uji normalitas, uji linieritas, uji multikolonieritas, dan uji heterokedastisitas. Uji normalitas dalam penelitian ini akan menggunakan uji Kolmogorov-Smirnov. Rangkuman hasil pengujian normalitas data dapat dilihat pada Tabel 03 .

Tabel 03. Rangkuman Hasil Uji Normalitas Data

\begin{tabular}{cccc}
\hline Residual Variabel & Ks Hitung & Ks Tabel & Keterangan \\
\hline $\begin{array}{c}\text { Kecerdasan Interpersonal terhadap Kompetensi Pengetahuan IPS } \\
\text { Aktualisasi Diri dalam Kelompok terhadap Kompetensi } \\
\text { Pengetahuan IPS }\end{array}$ & 0,0972 & 0,1055 & $\begin{array}{c}\text { Berdistribusi } \\
\text { Normal }\end{array}$ \\
$\begin{array}{c}\text { Berdistribusi } \\
\text { Normal }\end{array}$ \\
$\begin{array}{c}\text { Kecerdasan Interpersonal dan Aktualisasi Diri dalam Kelompok } \\
\text { terhadap Kompetensi Pengetahuan IPS }\end{array}$ & 0,0913 & 0,1055 & $\begin{array}{c}\text { Berdistribusi } \\
\text { Normal }\end{array}$ \\
\hline
\end{tabular}

Menurut Cahyono (2015) kriteria pengujian uji normalitas yaitu Kshitung < Kstabel berarti data distribusinya normal, sebaliknya bilamana Kshitung < Kstabel berarti distribusinya tidak normal. Berdasarkan hasil perhitungan tersebut, maka diperoleh data hasil penelitian berdistribusi normal.

Selanjutnya dilakukan uji linieritas. Menurut (Agung, 2014) "Uji linieritas dilakukan untuk mengetahui bentuk hubungan antara variabel terikat dengan masing-masing variabel bebas". Uji ini mengaplikasikan uji-F. Uji linieritas regresi dimulai dengan pengujian keberartian arah regresi. Harga $F_{\text {hitung }}$ dibandingkan dengan $\mathrm{F}_{\text {tabel }}$ dimana taraf signifikansinya 5\%. Menurut Koyan (2012) untuk menguji keberartian digunakan kriteria pengujian keberartian arah regresi yaitu bila $F_{\text {reg }}>F_{\text {tabel }}$ berarti koefisien regresi signifikan/berarti. Sesuai hasil analisis uji keberartian arah regresi, ringkasan hasil pengujiannya disajikan dalam Tabel 04.

Tabel 04. Rangkuman Hasil Uji Keberartian Linieritas

\begin{tabular}{cccc}
\hline Variabel & F reg & F tabel & Keterangan \\
\hline Kecerdasan Interpersonal terhadap Kompetensi Pengetahuan IPS & 4,88 & 3,89 & Berarti \\
Aktualisasi Diri dalam Kelompok terhadap Kompetensi Pengetahuan IPS & 4,96 & 3,89 & Berarti \\
\hline
\end{tabular}

Kemudian dilanjutkan dengan uji linieritas regresi. Harga $F_{\text {hitung }}$ yang diperoleh selanjutnya diperbandingkan dengan harga $\mathrm{F}_{\text {tabel }}$ di mana taraf signifikansinya 5\%. Kriteria pengujiannya ialah bila $F_{\text {tuna cocok }}<F_{\text {tabel, }}$, berarti bentuk regresinya tidak linier, tetapi sebaliknya bilamana $F_{\text {tuna cocok }}>F_{\text {tabel, }}$, berarti bentuk regresinya tidak linier. Sesuai hasil analisis uji keberartian arah regresi, ringkasan hasil pengujiannya disajikan dalam Tabel 05.

Tabel 05. Rangkuman Hasil Uji Lineritas Regresi

\begin{tabular}{cccc}
\hline Variabel & Ftuna cocok & F tabel & Keterangan \\
\hline Kecerdasan Interpersonal terhadap Kompetensi Pengetahuan IPS & 1,39 & 1,56 & Linier \\
Aktualisasi Diri dalam Kelompok terhadap Kompetensi Pengetahuan IPS & 1,09 & 1,66 & Linier \\
\hline
\end{tabular}

Berdasarkan hasil dari uji linieritas regresi tersebut maka bisa dirangkum bahwa pengujian keberartian dan linieritas kecerdasan interpersonal terhadap kompetensi pengetahuan IPS dan aktualisasi diri dalam kelompok terhadap kompetensi pengetahuan IPS yaitu berarti (signifikan) dan linier. Setelah dilakukan uji linieritas regresi maka uji asumsi selanjutnya yaitu uji multikolinieritas.

Menurut Supardi (2016:157) pengujian kolinearitas atau multikolinearitas dilakukan dalam rangka menguji apakah dalam model ganda ditemukan adanya korelasi antara variabel bebas. Dalam regresi yang baik syaratnya yaitu multikolinieritas tidak muncul di antara variabel bebas dalam model regresi. Pengujian multikolinearitas dilakukan dengan bantuan program SPSS 21.0 for windows dengan kriteria pengujiannya yaitu jika nilai Tolerance $\leq 0,1$ atau nilai VIF $\geq 10$, maka dikatakan terjadi kolineritas atau multikoleniaritas. Ringkasan hasil pengujian multikolinieritas disajikan pada Tabel 06. 
Tabel 06. Rangkuman Hasil Uji Multikolinieritas

\begin{tabular}{cccc}
\hline Variabel & Tolerance & VIF & Keterangan \\
\hline Kecerdasan Interpersonal & 0,948 & 1,054 & Tidak Terjadi Multikolinieritas \\
Aktualisasi Diri dalam Kelompok & 0,948 & 1,054 & Tidak Terjadi Multikolinieritas \\
\hline
\end{tabular}

Sebagaimana hasil analisis tersebut, mengidikasikan bahwa kecerdasan interpersonal dan aktualisasi diri dalam kelompok dengan nilai VIF = 1,054 yaitu di bawah 10 dan tolerance 0,948 melebihi 0,1 . Konklusinya yaitu tidak terdapat multikolinieritas antara variabel bebas. Selanjutnya dilakukan uji asumsi yang terakhir yaitu uji heteroskesdastisitas.

Uji heteroskesdastisitas bertujuan menguji muncul ketidaksamaan varian dari residual atau pengamatan ke pengamatan lainnya pada model regresi. Model regresi dianggap layak bila tidak muncul heterokedastisitas. Ada atau tidaknya heteroskesdastisitas bisa diidentifikasi melalui uji Glejser dengan mengaplikasikan SPSS Versi 21.0 for windows. Kriteria pengujiannya yaitu bila nilai sig > 0,05 berarti tidak muncul masalah heteroskedastisitas akan tetapi bilamana nilai sig $<0,05$ berarti muncul heteroskedastisitas. Ringkasan hasil pengujian uji heteroskesdastisitas disajikan pada Tabel 07.

Tabel 07. Rangkuman Hasil Uji Heteroskesdastisitas

\begin{tabular}{ccc}
\hline Variabel & Sig. & Keterangan \\
\hline Kecerdasan Interpersonal & 0,705 & Tidak Terjadi Heteroskesdastisitas \\
Aktualisasi Diri dalam Kelompok & 0,173 & Tidak Terjadi Heteroskesdastisitas \\
\hline
\end{tabular}

Dari uji heteroskesdastisitas, didapatkan nilai signifikan variabel kecerdasan interpersonal dan variabel aktualisasi diri melebihi 0,05 oleh karenanya dapat dikonklusikan bahwa tidak terjadi heteroskesdastisitas di kedua variabel tersebut. Setelah dilakukan uji asumsi, serta seluruh uji asumsi sudah terpenuhi, maka dilanjutkan pada pengujian hipotesis.

Berdasarkan hasil analisis uji hipotesis I, diketahui bahwa kecerdasan interpersonal terhadap kompetensi pengetahuan IPS siswa kelas V SD Gugus Budi Utomo Kecamatan Denpasar Timur Tahun Pelajaran 2019/2020 memiliki pengaruh yang signifikan dengan nilai thitung $=2,210$ dan nilai ttabel $=$ $1,97(\mathrm{n}=166)$ pada taraf signifikansi $5 \%$ yang berarti thitung $>$ ttabel. Sehingga $\mathrm{H}_{0}$ yang berbunyi tidak terdapat pengaruh yang signifikan kecerdasan interpersonal terhadap kompetensi pengetahuan IPS Siswa kelas V SD Gugus Budi Utomo Kecamatan Denpasar Timur Tahun Pelajaran 2019/2020 ditolak, sedangkan $\mathrm{H}_{1}$ diterima.

Melalui analisis regresi linier diperoleh persamaan regresi yaitu $Y^{\wedge}=68,603+0,125 X$ yang menandakan setiap kenaikan 1 skor kecerdasan interpersonal menyebabkan kenaikan sebesar 0,125 nilai kompetensi pengetahuan IPS pada konstanta 68,603. Persamaan regresinya diilustrasikan pada Gambar 01.

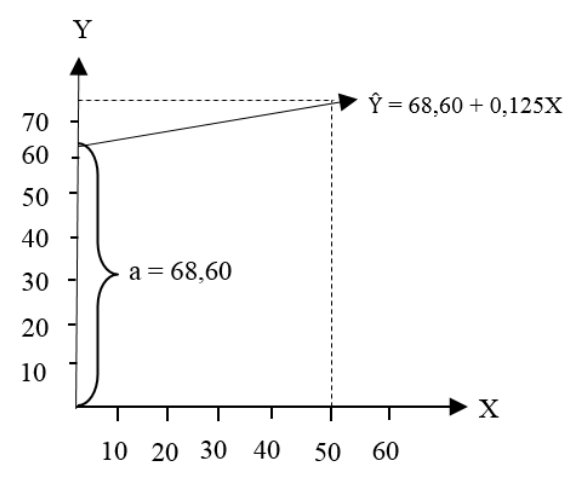

Gambar 01

Persamaan Garis Regresi $\hat{Y}=68,603+0,125 X$

Didasarkan pada ulasan tersebut, koefisien korelasi variabel kecerdasan interpersonal dengan kompetensi pengetahuan IPS adalah sebesar 0,22 dengan kecerdasan interpersonal memberi sumbangan efektif atau memiliki kontribusi sebesar 3,75\% sedangkan residunya sebesar $96,25 \%$ dipengaruhi faktor 
lain. Hal tersebut mengidikasi bahwa kecerdasan interpersonal menjadi faktor penunjang pencapaian kompetensi pengetahuan IPS. Tinggi atau rendahnya kecerdasan interpersonal siswa dipengaruhi oleh beberapa faktor seperti genetik, pola asuh, nutrisi, lingkungan, serta pengalaman hidup siswa. Selain kecerdasan interpersonal terdapat faktor lain yang mempengaruhi kecerdasan siswa yaitu faktor internal dan faktor eksternal. Faktor internal merupakan faktor yang berasal dari dalam diri siswa yang berupa motivasi belajar, konsentrasi belajar, rasa percaya diri, kebiasaan belajar, dan kemampuan dalam mengelola bahan belajar. Sedangkan faktor eksternal merupakan faktor pendukung yang berasal dari luar berupa faktor guru, faktor lingkungan, kurikulum sekolah serta sarana dan prasarana sekolah. Faktor tersebut juga mempengaruhi kompetensi pengetahuan IPS.

Menurut Safaria (2005:24) "Social insight yaitu kemampuan anak untuk memahami dan mencari pemecahan masalah yang efektif dalam suatu interaksi sosial, sehingga masalah-masalah tersebut tidak menghambat apalagi menghancurkan relasi sosial yang telah dibangun anak". Kecerdasan interpersonal juga dapat didefinisikan sebagai kemampuan dalam membedakan suasana hati,maksud,motivasi menganai perasaan orang lain serta kemampuan memberikan respons terhadapnya secara tepat terhadap suasana hati, temperamen, motivasi serta keinginan orang lain (Armanila, 2019). Terdapat beberapa cara untuk mengasah kecerdasan interpersonal siswa yang diungkap oleh Uno (2008) yakni berbagi rasa bersama teman sekelas, kerja kelompok, simulasi, dan memberikan permainan yang berkaitan dengan aktivitas sosial siswa sehingga membuat kecerdasan interpersonal berhubungan erat dengan pembelajaran IPS di sekolah karena pembelajaran IPS menekankan komunikasi, pembelajaran kelompok dan kemampuan siswa dalam menyampaikan pendapat sehingga terjadi interaksi sosial. Semakin tinggi kecerdasan interpersonal maka siswa memiliki hubungan sosial yang baik terhadap teman-temannya sehingga siswa yang memiliki kecerdasan interpersonal mudah memahami kompetensi pengetahuan IPS karena kompetensi pengetahuan IPS lebih banyak menyangkut tentang hubungan sosial, namun jika siswa memiliki kecerdasan interpersonal yang rendah maka siswa mengalami kesulitan dalam memahami kompetensi pengetahuan IPS karena kurangnya hubungan sosial. Siswa yang memiliki kecerdasan interpersonal yang rendah dapat menyebabkan siswa menjadi pasif dan cenderung acuh terhadap lingkungan sekitarnya sehingga kurang mampu berinteraksi dengan guru dan siswa lain dalam kegiatan pembelajaran serta mengalami kesulitan bekerja dalam kelompok dan cenderung dijauhi oleh siswa lain.

Berdasarkan hasil uji hipotesis I tersebut maka dapat diinterpetasikan, bilamana siswa mempunyai kecerdasan interpersonal yang tinggi, berarti ia memiliki nilai kompetensi pengetahuan IPS yang baik. sehingga kesimpulan dari hipotesis I yaitu terdapat pengaruh signifikan pada kecerdasan interpersonal terhadap kompetensi pengetahuan IPS siswa kelas V di sekolah tersebut.

Selanjutnya pada uji hipotesis II, diketahui bahwa aktualisasi diri dalam kelompok terhadap kompetensi pengetahuan IPS siswa kelas V SD Gugus Budi Utomo Kecamatan Denpasar Timur Tahun Pelajaran 2019/2020 memiliki pengaruh yang signifikan dengan nilai $t_{\text {hitung }}=2,227$ dan nilai $t_{\text {tabel }}=1,97$ (n $=166$ ) pada taraf signifikansi $5 \%$ yang berarti $t_{\text {hitung }}>t_{\text {tabel. }}$. Sehingga $\mathrm{H}_{0}$ yang berbunyi tidak terdapat pengaruh yang signifikan aktualisasi diri dalam kelompok terhadap kompetensi pengetahuan IPS Siswa kelas V SD Gugus Budi Utomo Kecamatan Denpasar Timur Tahun Pelajaran 2019/2020 ditolak, sedangkan $\mathrm{H}_{1}$ diterima.

Melalui analisis regresi linier diperoleh persamaan regresi yaitu $Y^{\wedge}=65,521+0,162 X$ yang menandakan setiap kenaikan 1 skor aktualisasi diri dalam kelompok menyebabkan kenaikan sebesar 0,162 nilai kompetensi pengetahuan IPS pada konstanta 65,521. Persamaan regresinya diilustrasikan pada Gambar 02.

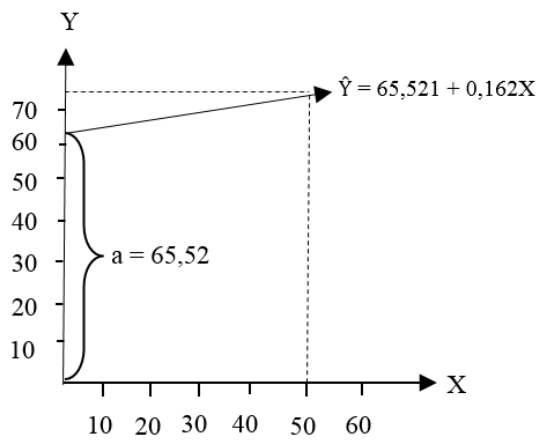

\section{Gambar 02}

Persamaan Garis Regresi $\hat{Y}=65,521+0,162 X$

Didasarkan pada ulasan tersebut, koefisien korelasi variabel aktualisasi diri dalam kelompok terhadap kompetensi pengetahuan IPS adalah sebesar 0,221 serta diperoleh sumbangan efektifnya sebesar 3,76\% sedangkan residunya sebesar $96,24 \%$ dipengaruhi faktor lain. Hal ini berarti bahwa 
aktualisasi diri dalam kelompok menjadi salah satu faktor yang mendukung pencapaian kompetensi pengetahuan IPS. Aktualisasi diri siswa di dalam kelompoknya dipengaruhi oleh berbagai faktor seperti potensi diri, hubungan interpersonal, faktor guru, kesiapan guru dalam mengajar, lingkungan siswa, budaya masyarakat, dan pola asuh orang tua. Faktor tersebut juga mempengaruhi kompetensi pengetahuan IPS siswa. Aktualisasi diri adalah penggunaan atau pemanfaatan bakat, potensi, pada diri individu secara penuh. Hal ini sejalan dengan pendapat Robbins dan Coulter (Widayanti; dkk, 2013) yang menyebutkan bahwa kebutuhan aktualisasi diri adalah kebutuhan seseorang untuk mampu menjadi apa yang diinginkan sesuai dengan potensi yang dimiliki.

Aktualisasi diri adalah penggunaan atau pemanfaatan bakat, potensi, pada diri individu secara penuh, berkemampuan untuk bisa menjadi apa yang diekspektasikan sebagaimana potensi yang dipunya. Maslow (Listyowati et al., 2011) menyatakan bahwa salah satu karakteristik anak yang memiliki aktualisasi diri adalah hubungan interpersonal. Anak yang memiliki aktualisasi diri akan lebih mampu bersosialisasi di lingkungan belajarnya di sekolah. Aktualisasi diri juga dapat didefinisikan sebagai perkembangan yang paling tinggi dari semua bakat, pemenuhan semua kualitas dan kapasitas, sesuai dengan potensi seseorang (Schultz, 1993:92). Apabila siswa mampu menata dan mengembangkan potensinya maka tentu mempermudah dalam mengikuti pembelajaran di sekolah. Seorang siswa yang mampu mengaktualisasikan diri di dalam kelompok mampu meningkatkan sikap saling menanamkan pemahaman antar anggota di dalam kelompok, yang terlaksanakan dengan adanya saling membantu antar anggota yang belum memahami materi dengan baik saat proses pembelajaran, mampu menyadari adanya kekurangan dan kelebihan setiap individu, yang terlaksanakan dengan sikap yang tidak meremehkan dan mendengarkan anggota lain serta menjadikan siswa harus mampu menjalin hubungan yang baik dengan anggota kelompok. Jika siswa memiliki aktualisasi diri di dalam kelompok yang rendah maka siswa mengalami kesulitan dalam memahami kompetensi pengetahuan IPS karena pembelajaran IPS di sekolah menekankan komunikasi serta pembelajaran berkelompok. Hal ini bermakna bahwa bila siswa mempunyai aktualisasi diri dalam kelompok yang tinggi, berarti ia memiliki nilai kompetensi pengetahuan IPS yang baik sehingga dapat dikonklusikan bahwa terdapat pengaruh signifikan pada aktualisasi diri dalam kelompok pada kompetensi pengetahuan IPS siswa kelas V di sekolah tersebut.

Uji hipotesis yang terakhir merupakan uji hipotesis III menggunakan uji regresi berganda yang diketahui bahwa kecerdasan interpersonal dan aktualisasi diri dalam kelompok terhadap kompetensi pengetahuan IPS siswa kelas V SD Gugus Budi Utomo Kecamatan Denpasar Timur Tahun Pelajaran 2019/2020 memiliki pengaruh yang signifikan dengan nilai $F_{\text {hitung }}=6,649$ dan nilai $F_{\text {tabel }}$ untuk (dk pembilang 2, dk penyebut 163) dan taraf signifikansi $5 \%$ yaitu 3,051. Ini berarti bahwa $F_{\text {hitung }}>F_{\text {tabel. }}$ Sehingga $\mathrm{H}_{0}$ yang berbunyi tidak terdapat pengaruh yang signifikan kecerdasan interpersonal dan aktualisasi diri dalam kelompok terhadap kompetensi pengetahuan IPS Siswa kelas V SD Gugus Budi Utomo Kecamatan Denpasar Timur Tahun Pelajaran 2019/2020 ditolak, sedangkan $\mathrm{H}_{1}$ diterima.

Melalui analisis regresi linier diperoleh persamaan regresi yaitu $Y^{\wedge}=48,596+0,163 X 1+0,209 X 2$ yang menandakan bahwa tiap kenaikan satu skor pada variabel kecerdasan interpersonal dan satu skor variabel aktualisasi diri dalam kelompok menyebabkan peningkatan kompetensi pengetahuan IPS sebesar 0,163 ditambah 0,209 pada konstanta 48,596. Persamaan regresinya diilustrasikan pada Gambar 03.

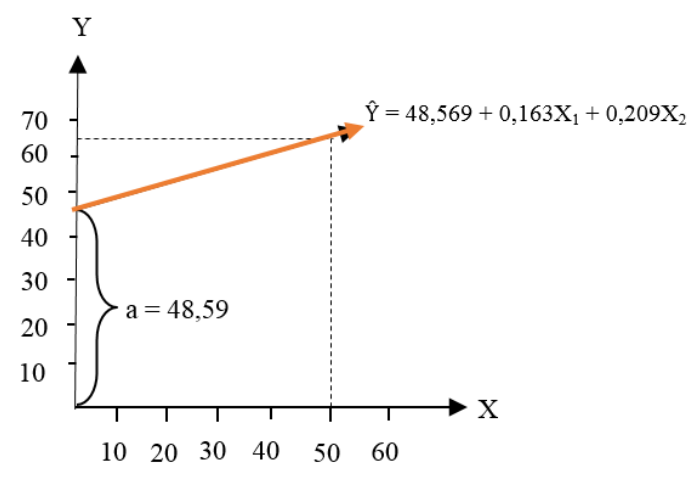

Gambar 03

Persamaan Garis Regresi $\hat{Y}=48,569+0,163 \mathrm{X}_{1}+0,209 \mathrm{X}_{2}$

Secara bersama-sama koefisien korelasi kedua variabel kecerdasan interpersonal dan aktualisasi diri dalam kelompok dengan kompetensi pengetahuan IPS pada siswa sebesar 0,274 dengan koefisien determinasinya sebesar 0,0751. Dapat diinterpretaikan bahwa kontribusi kedua variabel tersebut 
terhadap Kompetensi Pengetahuan IPS adalah sebesar 7,51\%. Siswa yang memiliki kecerdasan interpersonal dan dukungan aktualisasi diri yang positif maka siswa mampu memahami penguasaan kompetensi pengetahuan IPS karena salah satu karakteristik yang menunjukan seseorang mencapai aktualisasi diri adalah memiliki hubungan interpersonal yang baik. Hubungan interpersonal ini dipengaruhi oleh kecerdasan interpersonal siswa yang salah satu karakteristiknya adalah siswa dapat berkomunikasi dan berinteraksi dengan temannya. Dengan berinteraksi, siswa dapat mengukur potensi yang ada didalam dirinnya yang berarti siswa mampu menata dan mengembangkan. Dengan demikian maka orang yang mampu mengaktualisasikan diri mempunyai kecenderungan untuk menjalin hubungan sosial yang baik dengan orang lain (hubungan interpersonal) yang dipengaruhi oleh kecerdasan interpersonalnya sehingga siswa akan lebih mampu bersosialisasi di lingkungan belajarnya di sekolah terutama saat pemberian materi - materi IPS karena pada materi - materi IPS lebih menekankan pada komunikasi, pembelajaran kelompok dan kemampuan siswa dalam menyampaikan pendapat.

Berdasarkan hasil uji hipotesis tersebut maka dapat diinterpetasikan, bila siswa mempunyai kecerdasan interpersonal dan aktualisasi diri dalam kelompok yang tinggi, berarti ia memiliki penguasaan kompetensi pengetahuan IPS yang baik. sehingga penelitian ini memiliki konklusi yaitu terdapat pengaruh signifikan pada kecerdasan interpersonal dan aktualisasi diri dalam kelompok terhadap kompetensi pengetahuan IPS siswa kelas V di sekolah tersebut.

\section{Simpulan dan saran}

Berdasarkan hasil penelitian dan pembahasan, maka dapat ditarik simpulan sebagai berikut. (1) terdapat pengaruh yang signifikan antara kecerdasan interpersonal terhadap kompetensi pengetahuan IPS siswa kelas V SD Gugus Budi Utomo Kecamatan Denpasar Timur Tahun Pelajaran 2019/2020 dengan kontribusi sebesar 3,75\%, (2) terdapat pengaruh yang signifikan antara aktualisasi diri dalam kelompok terhadap kompetensi pengetahuan IPS siswa kelas V SD Gugus Budi Utomo Kecamatan Denpasar Timur Tahun Pelajaran 2019/2020 dengan kontribusi sebesar 3,76\% serta (3) terdapat pengaruh yang signifikan secara simultan antara kecerdasan interpersonal dan aktualisasi diri dalam kelompok terhadap kompetensi pengetahuan IPS siswa kelas V SD Gugus Budi Utomo Kecamatan Denpasar Timur Tahun Pelajaran 2019/2020 dengan kontribusi sebesar 7,51\%. Berdasarkan pada sumbangan yang diperoleh sebesar 7,51\%, dalam hal ini menunjukkan bahwa tidak hanya kecerdasan interpersonal dan aktualisasi diri dalam kelompok yang mempengaruhi kompetensi pengetahuan IPS, namun juga terdapat faktorfaktor lain yang mempengaruhi kompetensi pengetahuan IPS kelas V SD Gugus Budi Utomo Kecamatan Denpasar Timur Tahun Pelajaran 2019/2020 sebesar 92,49\%, baik itu faktor dari dalam diri siswa maupun dari luar diri siswa. Mengacu pada simpulan diatas dapat diajukan beberapa saran sebagai berikut. Bagi siswa, dalam setiap kegiatan pembelajaran, diharapkan siswa agar tidak pasif saat dilaksanakan pembelajaran kelompok, selain itu siswa juga sarankan untuk aktif mencari informasi dan pengetahuan agar tercipta suatu pembelajaran yang lebih bermakna sehingga siswa mampu membangun pengetahuannya sendiri untuk mengoptimalkan pencapaian kompetensi pengetahuan IPS. Bagi guru, lebih mengenal siswa, memberi inovasi dalam pembelajaran sehingga dapat menumbuhkan kecerdasan interpersonal dan aktualisasi diri siswa guru dapat dengan mudah mengoptimalkan pembelajaran IPS di kelas. Bagi kepala sekolah, dapat menyediakan sarana dan prasarana yang menunjang pembelajaran agar siswa semakin termotivasi untuk belajar dan memanfatkan sarana yang ada sehingga akan berdampak pada pencapaian kompetensi pengetahuan IPS. Bagi orang tua siswa, sebagai orang tua disarankan untuk untuk dapat lebih memahami tentang bagaimana kecerdasan interpersonal anak serta dapat dijadikan referensi bagi orang tua agar dapat memberikan arahan, dukungan dan memfasilitasi potensi yang dimiliki anaknya sehingga mampu mengaktualisasikan diri mereka sehingga anak merasa nyaman ketika belajar dan dapat meningkatkan pencapaian kompetensi pengetahuan siswa. Bagi peneliti lain, disarankan kepada peneliti agar hasil penelitian ini digunakan sebagai referensi untuk melaksanakan penelitian selanjutnya dan diharapkan penelitian ini bermanfaat bagi seluruh peneliti yang menggunakan penelitian ini.

\section{Daftar Rujukan}

Agung, A. A. G. (2014). Metodologi Penelitian Pendidikan. Aditya Media Publish.

Amalia, A. (2017). Pengaruh Kecerdasan Intrapersonal dan Interpersonal Terhadap Hasil Belajar IPS Siswa Kelas V Sd/Mi Se-Sarwas 1 Kecamatan Petarukan Kabupaten Pemalang. 
Amitha, A. F. (2016). Hubungan Kecerdasan Interpersonal Dengan Hasil Belajar pada Mata Pelajaran Ips Kelas V di SD intis School Yogyakarta. E-Jurnal Prodi Teknologi Pendidikan, 5(6), 139-154.

Arikunto, S. (2015). Dasar-Dasar Evaluasi Pendidikan. Bumi Aksara.

Armstrong, T. (2002). 7 Kinds of Smart. PT Gramedia Pustaka Utama.

Artha Saputra, Sujana, M. (2018). Korelasi Antara Kecerdasan Interpersonal Dengan Hasil Belajar IPS Siswa Kelas V di SD Gugus IV Abiansemal Tahun Pelajaran2017/2018. Indonesian Journal of Educational Research and Review, 1(1), 11-20. https://doi.org/10.23887/ijerr.v1i1.14618

Arum, A. (2017). Pengaruh Kecerdasan Intrapersonal dan Interpersonal tehadap Hasil Belajar IPS Siswa Kelas V SD/MI Se-Sarwas 1 Kecamatan Petarukan Kabupaten Pemalang. 2(1).

Ayu Wardani, N. M., Suniasih, N. W., \& Sujana, N. W. (2019). Korelasi Antara Konsep Diri dengan Kemampuan Pemecahan Masalah IPS. Thinking Skills and Creativity Journal, 2(1), 37. https://doi.org/10.23887/tscj.v2i1.18382

Daniati, Hermi Yanzi, Y. N. (2015). The of Extracurricular in Effect Fostering Potential to Students AT MA. Journal Education of Batanghari.

Dantes, N. (2012). Metode Penelitian. CV Andi Offset.

Daryanto. (2013). Siap Menyongsong Kurikulum 2013. Gava Media.

Giri, K. Y. Y., Suarni, N. K., \& Arini, N. W. (2018). Pengaruh Model Pembelajaran Kooperatif Script Berbantuan Media Audio Visual terhadap Hasil Belajar IPS Kelas IV. E-Journal PGSD Universitas Pendidikan Ganesha, 6(1), 63-72.

Kurniasih, dan B. S. (2014). Sukses Mengimplementasikan Kurikulum 2013. Kata Pena.

Listyowati, A., Andayani, T. R., \& Karyanta, N. A. (2011). Hubungan Antara Kebutuhan Aktualisasi Diri dan Dukungan Sosial dengan Kematangan Karir pada Siswa Kelas XII SMAN 2 Klaten. 000, 116-145.

Luh, N., Santiasih, A., Ganing, N. N., \& Sujana, I. W. (2016). Penerapan Talking Stick dalam Pendekatan Saintifik Pengetahuan IPS dan Motivasi Belajar siswa Kelas IV SDN 9 Padangsambian Universitas Pendidikan Ganesha.

Maslow, A. (1984). Motivasi dan Kepribadian (1st ed.). PT Gramedia.

Monawati. (2017). Hubungan Antara Kecerdasan Interpersonal Dengan Prestasi Belajar. Jurnal Pesona Dasar, 3(3), 21-32.

Muzamiroh, M. L. (2013). Kupas Tuntas Kuriulum 2013. Kata Pena.

Prawira, P. A. (2014). Psikologi Pendidikan dalam Perspektif Baru. Ar-Ruzz Media.

Ria Sabekti, Ah Yusuf, R. P. (2019). (Jurnal Keperawatan Jiwa). 1(2), 29-35. https://ejournal.unair.ac.id/PNJ

Safaria. (2005). Interpersonal Intelligence. Ambara Books.

Sakti, I. (2011). Korelasi Pengetahuan Alat Praktikum Fisika dengan Kemampuan Psikomotorik Siswa di SMA Negeri q Kota Bengkulu. Exacta, 9(1), 67-76.

Saputra, I. D. K. A. dkk. (2018). Korelasi Antara Kecerdasan Interpersonal dengan Hasil Belajar IPS Siswa Kelas V di SD Gugus IV Abiansemal Tahun Pelajaran 2017/2018. Indonesian Journal of Educational Research Dan Review, 1(1), 11-20.

Sudarsana, G. N. (2017). Pengaruh Cybertherapy terhadap Pengambangan Aktulisasi Diri Remaja Kelas XI SMA Negeri 1 Singaraja. Jurnal Ilmiah Pendidikan Dan Pembelajaran PPs Universitas Pendidikan Ganesha, 1(1), 20-31. 
Sudijono, A. (2015). Pengantar Evaluasi Pendidikan. Raja Grafindo Persada.

Sugiyono. (2017). Statistiak untuk Penelitian. Alfabeta.

Widayanti; dkk. (2013). Indonesian Journal of Guidance and Counseling: Theory and Application Hubungan Locus of Control dengan Motivasi Konselor. Indonesian Journal of Guidance and Counseling : Theory and Application, 2(3), 41-49. 